\title{
GRADE SCHOOL SEGREGATION: THE LATEST ATTACK ON RACIAL DISCRIMINATION*
}

Social scientists consider segregation to be a basic form of racial discrimination. ${ }^{1}$ Regulating the multitude of daily contacts between races, ${ }^{2}$ it has become the primary symbol of the Negro's inferiority. ${ }^{3}$ Because the school is society's chief agency for conserving and transmitting its culture, ${ }^{4}$ educa-

*Briggs v. Elliott, 98 F. Supp. 529 (E.D. S.C. 1951), remanded per curiam,-U.S.-, 96 L. Ed. 262 (1952) ; Brown v. Board of Education of Topeka, 98 F. Supp. 797 (D. Kall. 1951), appeal filed, 20 U.S.L. WEEK 3164 (Nov. 19, 1951).

1. "This is the main issue of contention of Negro protest: the exclusion from participation and integration on the basis of color in all varieties of social, educational, and political opportunities. This is the essence of discrimination. There is hardly a phase of living which is not encompassed by this type of discrimination against the Ncgro." Kardiner \& Ovesey, The MarK of Opression 61 (1951). For further discussion of segregation as a form of discrimination, see MYrdal, AN AMrkican Dilemina 581 (1944) (hereinafter cited as Myrdal); Davie, Negroes in American Societry 146-7 (1949) ; Bond, Education of the Negro in the American Social Order 385 (1934); Deutscher \& Chein, The Psychological Effects of Enforced Scgrcgation, $26 \mathrm{~J}$. of Psych. 259, 280 (1948) (hereinafter cited as Deutscher \& CheIN) ; Rose \& Rose, Americs Divided 167 (1948); Proceedings of the Mincentury White House Confrience on ChILdReN and Youth 175, 179 (1951) (hereinafter cited as Midcentury Wiutz House Conference).

One of the South's staunchest defenders of states' rights has candidly admitted, "Segregation is the most severe form of discrimination of which the Negro suffers. It is a fundamental discrimination." Collins, Whitrer Sold South? 141 (1947).

2. The primary objective of segregation is the reduction of social contact betwecn whites and Negroes. See Myrdal at 579. See also Doyle, THe EtrquetTe of Racial Retations IN THE South (1937).

3. See Mays, Improving the Morale of Negro Children and Youth, 19 J. Necko En. 420, 423 (1950); Beittel, Some Effects of the "Separate but Equal" Doctrine of Education, 20 J. Negro Ed. 140, 143 (1951); Midcentury White House Conference at 175 ; Davie, Negroes in North American Society 147 (1949).

4. "[I]t is the business of the school environment to eliminate, so far as possible, the unworthy features of the existing environment from influence upon mental habitudes. It establishes a purified medium of action. Selection aims not only at simplifying but at weeding out what is undesirable. Every society gets encumbered with what is trivial, with dead wood from the past, and with what is positively perverse. The school has the duty of omitting such things from the environment which it supplies, and thereby doing what it can to counteract their influence in the ordinary social environment. By selecting the best for its exclusive use, it strives to reenforce the power of this best. As a society becomes more enlightened, it realizes that it is responsible not to transmit and conserve the whole of its existing achievements, but only such as make for a botter future society. The school is its chief agency for the accomplishment of this end ... [I]t is the office of the school environment to balance the various elements in the social environment, and to see to it that each individual gets an opportunity to escape from the limitations of the social group in which he was born, and to come into living contact with a broader environment." DEWEY, Democracy AND Education 24 (1936). 
tional segregation has extra significance. A segregated educative system is likely to transmit to each succeeding generation the superiority-inferiority value attitudes of a racially conscious society. ${ }^{5}$ Furthermore, it provides public approval and reinforcement of private prejudices. ${ }^{\mathbf{6}}$

But legal judgment of the impact of educational segregation has not kept pace with social science judgment. Although racial discrimination is unconstitutional, segregation is not considered discriminatory if facilities are "separate but equal."7 The Supreme Court, in declining to outlaw segregation per se,

5. See Mincentury White House Conference at 175 ; Roberts, Some Mcutal and Enotional Health Needs of Negro Children and Youth, 19 J. NEGRo ED. 351,360 (1950); Browa, Educational Soctology 39, 275 (1947). It has often been observed that segregated schools block the Negro child's opportunity to share in democratic experience. See Johnson, Education and the Cultural Crisis 58-9 (1951) ; Jounson, Ixto the Mann Stream 175-6 (1947); Beittel, Some Effocts of the "Separale lut Equal" Doctrine of Education, 20 J. NEGRo Ed. 140, 143 (1951): Testimony of Dr. David Krech, Professor of Social Psychology, Univ. of California, Transcript of Record, Vol. II, pp. 159-60, Briggs v. Elliott, 98 F. Supp. 529 (E.D. S.C. 1951).

6. "The practice of segregation is, of course, not the only support of prejudice. But many people's attitudes of approving segregation-especially attitudes that are not very strong-are supported mainiy by observing the practice of segregation, as tangible evidence of what constitutes the social norms. If this support is removed, their attitudes are likely to be weakened. If, in addition ... the opposed attitude is now supported by the prestige of 'the law,' many people's attitudes toward segregation will be changed." Newconr, Soctal Psychology 609 (1950). For the growth of legislated segregation and a description of how, instead of merely reflecting the mores, it has tightened, frozen, and even instigated discrimination, see MIYRDAl at 578-\$2. See also Daniel, The Restonsibility of Education for the Preparation of Children and Youth to Live is a Multi-Racial Society, 19 J. NEgro ED. 38S, 395 (1950).

7. The "separate but equal' doctrine was adopted by the Supreme Court in Plessy v. Ferguson, 163 U.S. 537 (1896) to uphold a state law requiring segregation on public carriers. The Court acknowledged that racial discrimination was unconstitutional under the Fourteenth Amendment. Then, by gratuitously asstming that separation did not necessarily imply Negro inferiority, the Court reached its conclusion that if facilities were equal, segregation was not discriminatory. Id. at 543-4. But Justice Harlan, dissenting, said: "The arbitrary separation of citizens, on the basis of race . . . is a badge of servitude wholly inconsistent with the civil freedom and the equality before the lav established by the Constitution." Id. at 562 .

The Plessy doctrine was later applied to educational segregation cases and still controls. See Sweatt v. Painter, 339 U.S. 629, 635 (1950); Missouri ex rol. Gaines v. Canada, 305 U.S. 337, 344 (1938) ; Gong Lum v. Rice, 275 U.S. 78, 85-6 (1927) ; Briggs v. Elliott, 98 F. Supp. 529, 537 (E.D. S.C. 1951) ; Brown v. Board of Education of Topela, 98 F. Supp. 797, 800 (D. Kan. 1951).

However, the Plessy doctrine was not applied to residential segregation because this would deprive the Negro of the right to purchase and enjoy property. Buchanan v. Wariey, 245 U.S. 60, 78-9 (1917).

For discussion of the "separate but equal" doctrine and the Fourtcenth Amendment, see Frank \& Munro, The Original Understanding of "Fqual Protcetion of the Lanes," 50 CoL. L. Rev. 131 (1950); Ransmeier, The Fourteenth Amendment and the "Scharate but Equal" Doctrine, 50 Mrce. L. REv. 203 (1951); Roche, Education, Segregatioss and the Supreme Court-A Political Asalysis, 99 U. of PA. L. REv. 949 (1951).

8. Sweatt v. Painter, 339 U.S. 629, 636 (1950). 
has thus assumed the task of examining the facts of segregation, case by case, to see if any inequality has been shown. Using this method, the Court has made significant inroads on segregation at the graduate and professional level..$^{\circ}$ Focusing on intangibles such as the reputation of faculty and school in the profession, alumni position and influence and the composition of the student body, the Court has held separate facilities for Negroes on the graduate and professional level not equal to those provided white students. ${ }^{10}$

The drive against segregation has now shifted to the grade schools. In Briggs v. Elliott ${ }^{11}$ and Brown v. Board of Education of Topcka, ${ }^{12}$ stuch segregation has been squarely challenged in the Supreme Court for the first time. ${ }^{13}$

9. The Court has accomplished this by an increasingly rigorous definition of "equal facilities." Thus, the facilities must be within one's own state, Missouri $c \cdot x$ rcl. Gaines v. Canada, 305 U.S. 337, 349 (1938), and be available as soon as comparable facilitics are available to whites, Sipuel v. Board of Regents, 332 U.S. 631, 633 (1948). The tsse of intangible criteria of equality in Sweatt v. Painter, 339 U.S. 629 (1950) and McLaurin v. Oklahoma State Regents, 339 U.S. 637 (1950), see note 10 infra, has forced 11 out of 17 southern states to integrate schools at the graduate level. Konvitz, The Courts Deal a Blow to Segregation, 11 CoMsmentaRY 158, 162 (1951).

10. Sweatt v. Painter, 339 U.S. 629 (1950) held that Texas State University Law School, built especially for Negroes, was not equal to the white University of Texas Law School and therefore petitioner should be admitted to the white school. Id. at 635. The Court could have stopped with its finding of substantial inequality in number of faculty, course variety and specialization, size of student body, scope of library, and unavailability of a law review. But it went on to find great discrepancies in qualities "incapable of objective measurement." It felt that intangibles like faculty reputation, experience of the school's administration, its tradition and prestige in the community, and the position and infuence of the alumni were vital to an academic institution. $I d$. at 633 . Since petitioner's law school lacked representatives from the white $85 \%$ of the state's population, the school lacked the interplay of ideas and exchange necessary to the student lawyer who would have to deal professionally with that $85 \%$ in the form of lawyers, witnesses, jurors, judges, and officials. Id. at 633-4.

In McLaurin v. Oklahoma State Regents, 339 U.S. 637 (1950) the court held that once a Negro is admitted to graduate school, assigning him a designated place in the classroom, library, and dining room is a deprivation of equal protection even though he is in the same room as other students. Id. at 641. The court found that these scparations were more than nominal because the Negro was thereby set apart by the state in a manner that was a handicap to effective graduate learning. These restrictions were said to impair and inhibit the ability to study, discuss and exchange views, and learn a profession. The fact that his schoolmates could voluntarily refuse to associate with McLaurin was held irrelevant to the proposition that the state cannot deprive an indlvidual of the opportunity to gain acceptance on his own merits.

11. 98 F. Supp. 529 (E.D. S.C. 1951), remanded per curiam,-U.S.-, 96 L. Ed. (1952).

12. 98 F. Supp. 797 (D. Kan. 1951), appeal filed, 20 U.S.L. WeEK 3164 (Nov. 19, 1951).

13. The Supreme Court has repeatedly spoken of educational segregation as valid. Missouri e.x rel. Gaines v. Canada, 305 U.S. 337 (1938); Gong Lum v. Rice, 275 U.S. 78 (1927) ; Cumming v. Board of Education, 175 U.S. 528 (1899). But these cases did not rule on the question of whether segregation por se would be unconstitutional if objec- 
In the Briggs case, Negro parents argued that the educational segregation required by South Carolina's constitution and statutes is per se unconstitutional. ${ }^{14}$ They also alleged that the physical facilities afforded their children were inferior to those provided white children. ${ }^{15}$ In the Brotom case, a similar Kansas law is being attacked by Negro parents. ${ }^{16}$ In both cases special threejudge courts, relying on the "separate but equal" doctrine, sustained the constitutionality of the laws. ${ }^{17}$ In the Briggs case, however, the state conceded that the Negro facilities were not equal to the white and the court ordered equalization within six months. ${ }^{18}$ On the other hand, the Broum court expressly found respective Negro and white facilities substantially equal.19 Plaintiffs in both cases took direct appeals to the Supreme Court. The Supreme Court remanded the Briggs case and directed the three-judge court to evaluate South Carolina's effort to equalize facilities during the six

tive facilities were equal. See dissent of Edgerton, J., in Carr v. Corning, 182 F.24 14, 32 (D.C. Cir. 1950). See also Ransmeier, The Fourteenth Ancndnent and the "Scparate but Equal Doctrine," 50 MIICE. L. Rev. 203, 219 (1951); Waite, The Negro in the Supreme Court, 30 Minn. L. Rev. 254-5 (1945); Note, 56 Yale L. J. 1059 (1947). But see Briggs v. Elliott, 98 F. Supp. 529, 533 (E.D. S.C. 1951).

14. See S.C. Const. Art. 11, § 7: "Separate schools shall be provided for children of the white and colored races, and no child of either race shall ever be permitted to attend a school provided for children of the other race"; S.C. Coov $\$ 5377$ (1942): "It shall be unlawful for pupils of one race to attend the schools provided by boards of trustees for persons of another race."

15. Briggs v. Elliott, 98 F. Supp. 529,530 (E.D. S.C. 1951).

16. KaN. Stat. ANrs. c 72-1724 (1949) authorizes cities of the first class to organize and maintain separate schools for the education of white and colored children below the high school grades.

17. Briggs v. Elliott, 98 F. Supp. 529,536 (E.D. S.C. 1951); Brown v. Buard of Education of Topeka, 98 F. Supp. 797, 800 (D. Kan. 1951).

18. In the pleadings, the state denied that the facilities were unequal. But five months later, at the beginning of the hearing, it admitted physical inequality. The excuse advanced was that the school district was rural and lacked funds but that under the new South Carolina educational equalization bond issue, facilities would be greatly improved. Briggs v. Elliott, 98 F. Supp. 529. 531 (E.D. S.C. 1951). In deference to Siuth Carulina"s policy of segregation the court ordered prompt equalization rather than integration. Id. at 537-8. This order ignores the Supreme Court's decision that the right to equality is immediate under the Fourteenth Amendment. Sweatt v. Painter, 339 U.S. 629, 635 (1950) ; Sipuel v. Board of Regents, 332 U.S. 631, 633 (1948). In a strong dissent Judge Waring argued that the state's delayed admission of inequality was a maneuver to keep the court from reviewing the basic issue of whether segregation per se was unconstitutional. Id. at 540-41.

19. Quality and qualification of teachers, curricula, and physical facilities were found to be comparable. The court also decided that the longer distance Negroes had to travel to school was offset by free bus service. Brown v. Board of Education of Topela, 98 F. Supp. 797, 798 (D. Kan. 1951). This finding would seem to be an attempt to force a segregation per se ruling on the Supreme Court by eliminating the possibility of holding facilities unequal under the "separate but equal" doctrine. Conceivably, however, the Supreme Court will still find a way to avoid overruling Plessy. 
month period and to "take whatever action it may deem appropriate in light" of the present condition of the separate schools. ${ }^{20}$ On remand, the lower court held that the state has complied with the decree.21

Remand of the Briggs case indicates that the Supreme Court is not ready to overrule the "separate but equal" doctrine and will require a factual showing of inequality. Proving the inequality of physical facilities is relatively simple. 22 But where segregated facilities are physically equal, it becomes necessary to prove intangible inequalities if segregation is to be successfully attacked. These are more difficult to demonstrate at the lower levels of education than in professional schools because the impact of grade school education must be measured in terms of general personality development, ${ }^{\text {at }}$

20. Briggs v. Elliott, 20 U.S.L. WeEK 4112 (Jan. 28, 1952).

A third segregation case, recently decided in Virginia, held that facilities were not substantially equal and the court ordered the county's school authorities to equalize "with all reasonable diligence and dispatch." Davis v. School Board of Prince Edward County, Civil Action No. 1188 (D.C. Va. 1952) ; see N.Y. Times, Mar. 8, 1952, p. 15, col. 8.

21. N.Y. Times, Mar. 14, 1952, p. 25, col. 6.

22. Experience has shown that Negro facilities are never actually equal to the curriculum and physical plant provided for whites. This can be seen by a comparison of the statistics of teacher load, unit costs, teachers' salaries, and school term attendance. Blose \& Gucwa, Statistics of State School Systems. U.S. Office of Ed., BienNial Survey of Education in the United States 1946-48, 107 (1950) ('Table 45); Note, 56 YALE L. J. 1059, 1062 (1947) ; MYrDal at 581. Even Washington, D.C. schools, which are probably the best Negro schools in the country, have been found inferior. Strayer, The Report of a Survey of the Public Schools of the District or ColumiBIA 47-8, 315-21, 388 (1949). Threatened by integration, southern states are trying to improve their Negro schools. MYrdal at 342. For increase of expenditures between 1941 and 1948, see Bzose \& Gucwa, op. cit. supra, at 28 (Table XIX). South Carolinat plans to spend $\$ 75,000,000$, Briggs v. Elliott, 98 F. Supp. 529, 531 (E.D. S.C. 1951), and . Georgia $\$ 30,000,000$ on equalization. N.Y. Times, April 22, 1951, p. 58, col. 3. Sec generally Fine, Negro Education in South on Rise, N.Y. Times, March 16, 1952, p. 82, col. 3. But full equalization for the whole South, kindergarten through college, would probably cost close to a billion dollars-a prohibitive price for the comparatively poorer southern states. Konvitz, The Courts Deal a Blow to Segregation, 11 CoMmENTARY 158, 165-6 (1951).

Even if the separate system were equalized, segregation would still be discriminatory because intangible inequalities would remain. Beittel, Some Effects of the "Scparalc but Equal" Doctrine of Education, 20 J. NEGRo Ev. 140, 143 (1951).

Also, equalization within the uneconomical dual system would, per dollar spent, result in a lower standard of education than could be achieved on an integrated basis. Thus, both Negroes and whites will suffer an educational loss relative to the national average if the South is forced merely to equalize. However, since segregation is only economical if the South can maintain unequal facilities for Negroes, enforced equalization will constitute an economic pressure favoring desegregation. MYRDAL at 341-2.

23. Full group participation is crucial at the lower levels as an aid to personality development. American education seeks to help pupils develop habits of self-direction and cooperation by means of experimentation and participation in group life. Separatcness, by denying full participation, necessarily compromises the goals of self-realization, human relationship, and civic responsibility. Educational Policies Commission, Na- 
while the impact of graduate school training can also be evaluated in terms of preparation for professional work. Since personality reflects the total life experience of any given individual, it is difficult to isolate the specific psychological impact of segregation upon the individual personality. The presence of other forms of social discrimination prevents scientific measurement of educational segregation's precise effect. ${ }^{24}$ It seems reasonable, however, to infer that the contribution of educational segregation to the total impact of discriminatory experiences affecting the Negro is substantial..$^{20}$

In the Briggs case, efforts were made to demonstrate the effects of segregation by introducing into evidence the results of psychological projective tests ${ }^{20}$

tronal Education Association, Education for All Asrekrcan Chmonen 112 (1948); Johrson, Education and the Cultural Crisis $58-9$ (1951); Killp.trRick, Bode, Dewey, Chinds, Roup, Hullfish \& Thayer, The Educational Frontrez 190-191 (1933); MIDCENTURy White House Conference at 175-6.

24. Social scientists admit that we have not yet reached the point where we can measure the effects of separate factors of discrimination on the individual personality. Kardiner \& Ovesey, The Mark of Oppression xiv (1951); Sutnerlas: Colo3, Class, and Personality xxiii (1942) ; Long, Some Psychogenic Hazard's of Segregated Education of Negroes, 4 J. NeGro Ed. 336 (1935).

For the latest psychodynamic material in the general field, see KAsDiner \& OvzsEr, op. cit. supra. Psychological projective tests have been used with children to explore the growth of attitudes toward racial difference. See note 26 infra. However, empirieal professional experience and observation remain the chief basis for the overwhelming social science opinion that segregation is inherently harmful. Deutscres \& CuEr:i at 270, 271.

25. Dr. Frederick Wertham, noted psychiatrist, testified recently that although he recognized that educational segregation is not the sole cause of emotional conflict among Negro children, it is of "paramount importance." Its force is significant to Dr. Wertham because it is a clear cut, continuous act of the state bound up with the educative process which hits the child at the moment he leaves a sheltered family life to contact society and for the first time find social groups for himself. Transcript of Record, p. 137-9, Bulah v. Gebhart, Delaware Chancery Civil Action No. 265, Oct. 25, 1951.

Recently a survey of social scientists was taken to try to focus the expert opinion of anthropologists, psychologists, and sociologists on the effects of enforced segregation, assuming facilities were equal. These experts were picked as scientists especially concerned with social adjustment of individuals from membership lists of the respective learned societies. The sociological sample was split into two groups: (a) those who listed race relations or social psychology as a dominant interest; and (b) "selected sociologists" who had published research on race relations in either the Ancrican Journal of Sociology or the American Sociological Review. A total of 849 questionnaires were sent out. $90.4 \%$ of the 517 replies stated that enforced segregation vould have detrimental effects on the segregated group even if equal physical facilities are provided. Only 2.3\% said it would not have this effect while $7.4 \%$ did not answer or had no opinion. 82.8\% also felt that segregation had detrimental effects on the segregating group while $3.7 \%$ said no and $13.5 \%$ did not commit themselves. DeUtscrer \& CaEs: at 266-7.

26. Projective tests seek to reveal conscious and unconscious attitudes or feelings by use of pictures, toys or dramatic play techniques which do not commit the subject upon issues explicitly formulated. For a full description, consult Horowitz \& Murphy, Projective Methods in the Psychological Study of Children, 7 J. ExP. ED. 133 (1938).

The doll and picture-coloring tests used here sought to establish in this order (a) racial preference (b) ability to distinguish racial differences and (c) racial self-identifie- 
given to sixteen Negro school children involved in the controversy. The tests were similar to tests previously given to a larger sample of Negro children three to seven years old from both mixed and segregated nurseries and schools of the North and South. ${ }^{27}$ The children in both tests were given a colored and a white doll, which were otherwise identical. They were asked to choose the "nice" doll, the "bad" looking doll, the "nice" color, and the doll they would prefer to play with. After these value judgments had been expressed, each child was asked to point out in turn the white doll, colored doll, Negro doll, and finally the doll that looked like himself. ${ }^{28}$ Examination of total restults shows a marked conflict between racial preference and racial self-identification. In the broader sample, two-thirds of the children preferred the white doll and 59 per cent expressed the more negative view that the colored doll looked "bad." At the same time two-thirds of the children identified with the colored doll. ${ }^{29}$ The Briggs test produced similar results. ${ }^{30}$ These children would seem

tion. For example, each child, after being given dolls identical except for color, was asked this series of questions: "Give me the: (1) doll you like best or like to play with; (2) 'nice' doll; (3) doll that looks 'bad'; (4) doll that has the nice color; (5) doll that looks like a white child; (6) doll that looks like a colored child; (7) doll that looks like a Negro child; (8) doll that looks like you." Clark \& Clark, Racial Identification and Preference in Negro Children in Readings in Social. Psychology 169 (Newcomb \& Hartley ed. 1947) (hereinafter cited as CLARK \& CLARK).

27. Ibid. Dr. Kenneth B. Clark, Assistant Professor of Psychology, New York City College, also tested the sixteen children in the Briggs case a week before trial. Transcript of Record, Vol. I, p. 89, Briggs v. Elliott, 98 F. Supp. 529 (E.D. S.C. 1051). For results of related tests see Clark \& Clark, Emotional Factors in Racial Identification and Preference in Negro Children, 19 J. Negro Ev. 341 (1950); Clark \& Clark, Skin Color as a Factor in Racial Identification of Negro Preschool Children, $11 \mathrm{~J}$. Soc. Psych. 159 (1940); Clark \& Clark, Segregation as a Factor in the Racial Identification of Negro Preschool Children, 11 J. Exp. Ev. 161 (1939) ; Clark \& Clark, The Development of Consciousness of Self and the Emergence of Racial Identification in Negro Preschool Children, 10 J. Soc. Psych. 591 (1939); Horowitz, Racial Aspects of Silf Identification in Nursery School Children, 7 J. PsxcH. 91 (1939).

A forthcoming book on the effects of discrimination, by Dr. Kenneth C. Clark, will bring together for critical analysis all of the latest psychological experiments used by the Midcentury White House Conference on Children and Youth.

28. There was little chance of error from mistaken color selection since $94 \%$ of the children in the broader sample correctly identified the white doll as looking like a white child. Clark \& CLARK at 171. All sixteen of the children tested for the Briggs case correctly identified the dolls as to racial likeness. Transcript of Record, Vol. I, p. 90, Briggs v. Elliott, 98 F. Supp. 529 (E.D. S.C. 1951).

29. CLARK \& C C LARK at 175. This preference is corroborated by the fact that a majority of children at every age level except seven chose white as the "nice" color. At seven the children split evenly on which color was "nice." Id. at 176.

30. Of the sixteen Briggs case children tested ten preferred the white doll and six the colored doll; nine considered the white doll to be the "nice" doll and seven the colored doll; and eleven said the colored doll looked "bad." The remaining four children made no choice at all. Transcript of Record, Vol. I, p. 90, Briggs v. Elliott, 98 F. Supp. 529 (E.D. SC. 1951). 
either to be in conflict about their status or to have resigned themselves to inferior self-images. Those who identify themselves as white either have a confused self-image or are escaping from the reality of inferior status. ${ }^{31}$

The unhealthy symptoms revealed by the doll tests cannot, however, be traced with certainty to educational segregation. A North-South brealidown of the results fails to establish any statistically significant difference in the preference for the white doll or self-identification with it.32 And analysis of the tests by age groups shows that Negro children are already aware of race and accompanying value judgments at the preschool age. ${ }^{33}$ This rules out the possibility that the schools play an initiating role in creating psychological conflicts. The tests do indicate that the age of starting school is a crucial one in the development of the child's ego structure. Because he seeks positive group identification and personal self-esteem, the tests show that the child at this time is especially sensitive to the accepted social values of his larger environment. $^{34}$ But psychologists have not yet gone far enough to produce findings that can compel direct legal consequences under the "separate but equal" doctrine. ${ }^{35}$

31. Transcript of Record, Vol. I, pp. 90-91, Briggs v. Elliott, 98 F. Supp. 529 (E.D. S.C. 1951). See also Clark \& Clark, Enotional Factors in Racial Identification and Preferente in Negro Children, 19 I. NEGno Ev. 341, 349-50 (1950).

32. C C IARK \& $C_{\text {LARK }}$ at $174,178.69 \%$ of the southern children identified with the colored doll but only $61 \%$ of the northern children did so. This can be partially accounted for by the fact that the northern sample had more light-skinned Negroes. Id. at 177.

$72 \%$ of the northern children preferred to play with the white doll compared with $62 \%$ of the southern children. $68 \%$ of the northern children chose the white doll as "nice" compared with $52 \%$ of the southern. The only statistically significant differential was that $71 \%$ of the northern children chose the colored doll as "bad" compared with only $49 \%$ of the southern children. Answering the "nice color" question, $63 \%$ of the northern and $57 \%$ of the southern children picked the white doll. Ibid.

These figures at first glance would seem to indicate that the South with its segregated schools provides a healthier environment for Negro children. Dr. Clark feels that this would be an inaccurate and superficial analysis. He concedes that there is more overt conflict present in the northern children but stresses the fact that submission and apparent adjustment to inferior status are also unhealthy. Communication to the YaLE LAw Journal from Dr. Kenneth B. Clark, dated Feb. 19, 1951, in the Yale Law Library.

It is clear, however, that these tests do not isolate school segregation as the source of emotional disturbances in Negro children. Also, since the Negro facilities in the Briggs case were inferior, the tests cannot demonstrate specifically that "separate but equal" facilities harm the Negro child.

33. CIARK \& CLARK at 174.

34. Id. at 177. At the ages of five and six both northern and southern Negro children showed the greatest preference for the white doll in their value judgments of "play with," "nice," and "nice color." Id. at 176. This corresponds roughly with the age at which most children leave the home and must adjust to groups in the wider school community. For an indication of the importance of this period in the life of the child, see testimony of Dr. Wertham, supra note 25.

35. The Court could, of course, draw an inference similar to those made in the Sweatt and McLaurin cases. For instance, the court in Brown v. Btard of Edueation of 
Behind the Supreme Court's insistence on a factual showing of inequality in educational segregation cases may be a reluctance to remove too abruptly the basic props of the Southern social system. In part this reluctance may stem from fear that sudden change would have harsh effects on Negro children presently in school. Forcing them into a hostile mixed school atmosphere might during the transition produce more unfortunate psychological consequences than segregation. $^{36}$ However, since this may also occur when segregation is abolished piecemeal, some immediate harm to Negro children seems inevitable if the long-run goal of a healthy educational environment for both Negroes and whites is to be achieved..$^{37}$ A more decisive factor in the Court's "go slow" policy may be its fear of precipitating widespread social unrest and possible

Topeka, 98 F. Supp. 797, 800 (D. Kan. 1951) found it difficult to see why segregation in separate schools was not unconstitutional if segregation within a school was held illegal in the McLaurint case. Nor could the district court see why commingling with the white majority group was any less educationally advantageous in the lower grades than at the graduate level. But the court felt bound by Plessy v. Fergison until that case is overruled. Id. at 800 .

In attempting to prove the psychological impact of segregation the Negro secks to convince the Supreme Court that segregation necessarily creates inequality and hence must be held unconstitutional' per se. Such a holding would put an end to lengthy litigation. But there is no way to prevent the Court from insisting that proof of a deleterious psychological impact in one case does not prove it for other cases. Thus the Court may continue to decide segregation on a case to case basis under the "scparate but equal" rule. Another purpose of proving psychological or intangible inequalities is the fact that unlike physical inequalities they probably cannot be remedied by equalization.

36. Dr. W. E. B. DuBois expressed this concern when he said that the Negro school child needed sympathy and understanding which he would be unlikely to get in a mixed school since private discrimination would continue and white teachers were unequipped to offset it. He also felt that the truth about Negro history, necessary to give the Negro child proper status, would only receive adequate attention in a Negro scliool. Although Dr. Du Bois criticizes using the child as a "battering ram" for reform, he was mainly critical of overemphasis on desegregation to the detriment of equalization. He concedes that a mixed school offers the more natural basis of corrective education because of the wider contacts. DuBois, Does the Negro Need Separate Schools?, 4 J. NEGRO ED. 328 (1935).

Dr. Henry B. Garret of Columbia University is the only recent authority to claim that given equal facilities, Negro students can get a better education in a segregated school. N.Y. Times, Mar. 1, 1952, p. 13, c. 4.

37. There is considerable expert testimony to the effect that the self-image conflict of Negro children will never be corrected in segregated schools because the fact of segregation gives objective support to their inferior status. Testimony of Dr. Datvid Krech, Associate Professor of Social Psychology, University of California, Transcript of Record, Vol. II, p. 159; Brìggs v. Elliott, 98 F. Supp. 529 (E.D. S.C. 1951) ; testimony of Mrs. Helen Trager, M.A., teacher and lecturer at Vassar College, id. at Vol. II, pp. $171,182$.

Dr. Wertham, after testing and interviewing pupils of segregated schools, concluded that segregation created an insoluble emotional conflict in the mind of the Negro. He said that legislated educational segregation acted to intensify the conflict and was the most important factor impairing the mental health of Negroes. N.Y. Times, Oct. 23, 1951, p. 23 , col. 5 . 
violence. ${ }^{38}$ This fear could easily arise from repeated warnings of southern leaders that no interference with the established Southern racial structure will be tolerated. ${ }^{39}$ But an examination of the available evidence malies it doubtful that major violence would accompany educational desegregation. ${ }^{20}$

Despite extensive educational desegregation, in only one city was there any violence during the transition. ${ }^{41}$ As a result of recent Supreme Court cases, over a thousand Negroes have been peacefully integrated into southern graduate and professional schools. ${ }^{42}$ Social ostracism has not been as great

38. Thus, southern briefs defend segregation as a public safety necessity. Brief of the States of Arkansas, Florida, Georgia, Kentuchy, Louisiana, Mississippi, North Carolina, Oklahoma, South Carolina, Tennessee and Virginia, amici curiae in support of Respondents, p. 9, Sweatt v. Painter, 339 U.S. 629 (1950).

Technically, of course, this policy element cannot control the legal issue. But it is generally recognized that the Court avoids a per se ruling because it is reluctant to cause social revolution by judicial fiat. Berger, The Sutreme Court and Group Discrintisation since 1937, 49 Col. L. Rev. 201, 204; Comment, 18 U. of CHI. L. Rev. 769, 781, (1951); Note, 56 YALE L J. 1059, 1067 (1947). For a full discussion of the issue's political implications, see Roche, Education, Segregation and the Supreme Court-A Political An:alysis, 99 U. OF PA. L. REv. 949 (1951).

A counter policy argument is developing as a result of the growing embarrassment caused to American international prestige by domestic American racial conditions. Drals, The International Intplications of Race and Race Relations, 20 J. Necro En. 261 (1951); Bunche, Denocracy: $A$ World Issuc, 19 J. Necro Ev. 431, 436-7 (1950).

39. E.g. Governor Wright of Miss. in an unprecedented state-wide radio hools-up warned Negroes that his state would not tolerate integration even if passed by Congress: "If any of you have become so deluded as to want to enter our white schools, patronize our hotels and cafes, enjoy social equality with whites, then lindness and true sympathy requires me to advise you to make your home in some other state than Mississippi." N.Y. Times, May 10, 1948, p. 5, col. 5; similarly, Governor Talmadge has predicted riots if Negroes enter white schools, id., Sept. 26, 1950, p. 22, col. 3, and says that Georgia will continue to bar Negroes so long as he is governor, id., June 6, 1950, p. 19, col. 2. Governor Byrnes in repudiating the Truman Administration's efforts to end segregation, id., Jan. 17, 1951, p. 3, col. 2, has pledged continued segregation for South Carolina. Id., Jan. 25,1951 , p. 19 , col. 6 .

40. Although there can be no guarantee of non-violent reaction to desegregation, threats in the past have failed to materialize. See note 51 infro. A recent analysis of racial violence concluded that most if not all racial violence can be prevented by welladvised government action even where the enforcement of civil rights involves a direet attack on racial segregation. Comment, Racial Violensee and Cizil Rights Law Enforecment, 18 U. OF CHI. L. REv. 769, 781 (1951).

41. Protest meetings, demonstrations, and school strikes are considered here to be peaceful and lawful methods of registering protest. The only reported incidents of violence stemming from educational desegregation are the recent disorders in Cairo, Ill. See note 47 infra.

42. These results are unquestionably attributable to the Supreme Court decisions in Sweatt v. Painter, 339 U.S. 629 (1950) and MicLaurin v. Oklahomz State Regents, 339 U.S. 637 (1950). The New York Times surveyed one hundred institutions and found that the same officials who had predicted campus and community riots if integration occurred freely admitted that the transition had not disturbed institutional routine. N.Y. Times, Oct. 23, 1950, p. 29, col. 6: id.. Oct. 29, 1950, p. 9, col. 2 . 
as was expected. ${ }^{43}$ Furthermore, in Illinois, ${ }^{44}$ Indiana, ${ }^{45}$ and New Jersey, ${ }^{40}$ state legislatures have forced reluctant communities to eliminate segregation in their grade schools. Despite local resentment and protest, the integration of Negro and white children has generally proceeded peacefully. ${ }^{47}$

43. Ibid. For a review of graduate level desegregation, the reception of Negrocs, and the lack of violence or injury to race relations, see ANERICAN JEwISH Congress \& Natronal Assoctation for the Advancement of Colored People, Civil Riauts in the United States in 1950: A Balance Sheet of Group Relations 42-6, 51-2 (hereinafter cited as 1950 BALANCE SHEET). Campus newspapers at the Universiticg of Alabama and Mississippi, Auburn College, and Millsaps College openly endorsed integration. Konvitz, The Courts Deal a Blow to Segregation, 11 Coumentary 158, 164 (1951).

It is not yet clear how far undergraduate schools will be affected by the Sweatt and McLaurin cases but in at least three states private colleges have voluntarily desegrcgated. See 1950 Balance Sheet at 46 . Kentucky amended its laws to allow integration above the high school level, Ky. Rev. Stat. $§ 158-021$ (Supp. 1950), and five institutions promptly dropped segregation. 1950 BaLANCE SHEET at 46; 123 New Republic 9 (1950). See also Konvitz, supra, at 165.

44. In 1950, East Louis, Ill., ended its eighty-five year old segregation of schools. Although police were alerted and some white pupils stayed home, no incidents werc reported. N.Y. Times, Jan. 30, 1950, p. 22, col. 4; id., Jan. 31, 1950, p. 16, col. 3. This integration was forced on East St. Louis by the Illinois legislature which voted to cut off the state subsidy to any school violating state law by separating Negro and white pupils. Id., Dec. 22, 1949, p. 8, col. 3. But cf. the situation in Cairo, Ill., note 47 infra.

45. In Indianapolis, where segregation dated from 1875, and was well entrenched because of the strong Ku Klux Klan tradition in Indiana and the proximity to the South's Jim Crow, desegregation was expected to bring trouble. For an account of these expectations and their peaceful outcome see Lewis, The Crisis That Never Came Off, The Reporter, Dec. 6, 1949, p. 12. Over fervent protests the Gary, Indiana school board successfully desegregated one of its main high schools without violence although at onde point 1500 of its 1750 pupils were out on strike. N.Y. Times, June 7, 1947, p. 30, col. 7; id., Sept. 4, 1947, p. 19, col. 5; id., Sept. 5, 1947, p. 21, col. 6; id., Sept. 6, 1947, p. 2, col. 1 ; id., Sept. 7, 1947, p. 14, col. 4; id., Sept. 8, 1947, p. 23, col. 6; id., Sept. 9, 1947, p. 25 , col. 6 ; id., Sept. 13, 1947, p. 2, col. 3.

46. The New Jersey Constitutional Convention adopted a ban on public school segregation in 1947. N.Y. Times, Aug. 21, 1947, p. 25, col. 5. And desegregation has been systematically enforced since 1948 . Id. Feb. 5, 1948, p. 14, col. 3; id., Feb. 20, 1948, p. 16, col. 3 ; id., June 5, 1948, p. 18, col. 7. Although there are still some all-Negro schools due to geographical situations, forty school districts had desegregated without reported violence as of Sept. 24, 1951. New Jersey Department of Education, Division Against Discrimination, Progress Report on the Desegregation of Schools (1951).

47. The very recent limited bombing and cross-burning in Cairo, Ill., is the sole reported example of violence stemming from educational desegregation. The incidents were threats to discourage integration and proper police protection was conspicuousiy absent. Time, Feb. 18, 1952, p. 67; The Nation, Feb: 2, 1952, pp. 124-6. Subserutuntly, 21 Negro children were integrated into white schools with no reported incidents. N.Y. Times, March 2, 1952, p. 71, col. 5.

Extensive integration over protests has occurred in Arizona without any violence. Communication to the Yale Law Journal from Arizona Council for Civic Unity, dated Jan. 2, 1952, on file in Yale Law Library; Time, Oct. 8, 1951, pp. 84-5. 
Other forms of desegregation have recently occurred in the South, and despite sporadic racial violence the transition has in general been peaceful. In some instances, the desegregation has occurred in activities where southern insistence on segregation has traditionally been most adamant. Thus, in St. Louis and Washington, D.C., over strong public protest, segregation in municipal swimming pools has been successfully prohibited. $\$$ Experience in the elimination of segregation in public parks, sporting events, theaters and movies has been the same. ${ }^{49}$ And in the armed forces, where resistance to racial integration has been traditional, segregation is fast disappearing at the command of the President. ${ }^{50}$ In allied fields of racial discrimination, such as

48. Interracial swimming carries sexual connotations and therefore is second in Myrdal's "Rank Order of Discriminations" as supported by white public opinion. MYrdal at 61,617 . Despite a forced closing due to a riot in 1949, N.Y. Times, June 22, 1949 , p. 56, col. 3, the St. Louis, Mfo., municipal swimming pool was opened by court order, id., July 18, 1950, p. 13, col. 2, and operated interracially without serious disturbance in 1950. Better preparation was made and after the first days extra police supervision was discontinued. 1950 Balance SheEt at 66. However, a near riot had to be quelled at Colonial Beach, Va., when Negroes tried to swim there. Ibid. In Washington, D.C., the Department of the Interior pools were interracial in 1950 with an estimated 145,000 whites and 90,000 Negroes attending without incident. Id. at 74. But a race riot had closed them in 1949. N.Y. Times, July 1, 1949, p. 22, col. 3. For a detailed discussion of the swimming pool desegregation in St. Louis and Wash., D.C., see Comment, Racial Violence and Ciril Rights Enforcement, is U. of CHI. L. REv, 769, 771-5 (1951).

49. Baltimore, Md., has ended segregation on four golf courses and allows mixed tennis matches on some of its city courts. N.Y. Times, June 27, 1951, p. 22, col. 6.

The South has had' several major sports events with Negro-white participation. N.Y. Times, Sept. 21, 1947, § V, p. 4, col. 5; id., Oct. 13, 1947, p. 34, col. 4; id., Nov. 24, 1947, p. 25 , col. 2. The University of North Carolina recently stopped requiring segregation of its Negro students as spectators, id., Oct. 13, 1951. p. 7, col. 8. However there has been a tendency toward voluntary self-segregation. Id., Oct. 14, 1951, p. 39, col. 4.

Several theatres in Washington, D.C., 1950 B.luxce Subet at 76; N.Y. Times, Sept. $11,1949 \$ 11$, p. 3 , col. 8 , and six motion picture houses in Wilmington, Del. have successfully dropped segregation without disturbing public order. Id., Miarch 10, 1951, p. 8, col. 1. For a survey of recent desegregation generally, see 1950 Barawice Shert.

50. Exec. Order No. 9981, 13 FED. REg. 4313 (1948) called for "equality of treatment and opportunity for all persons in the armed services without regard to race, color, religion or national origin." This order resulted in an official policy and implementation of racial integration in all three services. Report ay the Presmentr's Commitree os: Equautr of Treatmient ANd Opportunity in the ARsird Services 5-7 (1950). Integration of work, school, and living quarters, which was fastest in the Navy and Air Force, resulted in a decrease of racial friction, rather than greater tension. Id. at 44. Segregation policy in the Army was traditionally justified by the military opinion that it was necessary for morale and efficiency. This rationalization has been discredited and integration is the official policy and practice in the Army. Id. at 47-63. For the complete history of Navy integration, see Nelson, Integration of the Negro into the United States Nam: (1951). Desegregation in the armed forces would have been stopped had it impaired efficiency or morale. Exec. Order No. 9981, 13 FED. REG. 4313 (1948). And its success should establish the feasibility of integration in other areas of life, especially in schools where life contacts are far less constant and intimate. 
white primaries, ${ }^{51}$ all-white juries ${ }^{52}$ and segregated interstate travel, ${ }^{50}$ court orders have partially overcome deeply rooted patterns of discrimination. All of this progress has been made in the face of continuous threats of violence and non-conformance by southern leaders. ${ }^{54}$

51. For a succinct history of the court battles to outlaw white primaries and circumvention tactics in the South, consult KeY, Soutrern Politics c. 29 (1949). On Negro suffrage in general see Logan, Amtitude of the Southern White Press toward Negro Suffrage (1940); Moon, Balance of Power-The Negro Vote (1948).

Southern threats against Negro voting never materialized. Despite the exhortations of Senator Bilbo and others to use any means to bar the Negro vote, N.Y. Times, June 23,1946 , p. 30 , col. 4 , and his assertions to the effect that whites would continue to run the Mississippi primary, id., June 25,1946 , p. 17, col. 5, only a few incidents were reported as Negroes voted for the first time. Id., July 3, 1946, p. 1, col. 2; id., July 4, 1946, p. 1, col. 6. Despite warnings from Governor Talmadge, Negroes voted in the Georgia primaries and no incidents were reported. Undoubtedly some Negro voters stayed away from the polls but Negro participation in the primary voting was encouraging. Id., Aug. 17, 1946, p. 11, col. 7. A study shows that Negro suffrage in Texas has been accepted with very little resort to extra-legal violence despite an ever-increasing Negro vote. Strong, The Rise of Negro Voting in Teras, 42 AMr. PoL. Scr. Rev. 510, 512-13 (1948).

Former Federal District Judge Waring, who wrote the decision outlawing South Carolina's white primary system, Rice v. Elmore, 165 F. 2d 387 (4th Cir. 1947), ccrt. denied, 333 U.S. 875 (1948) (unsuccessful attempt to avoid the rule of Smith v. Allwright, 321 U.S. 649 , by repealing all the South Carolina laws relating to primarics in order to make the South Carolina Democratic party a private organization not subject to constitutional restriction) later asserted that the peaceful 1948 primarics demonstrated the emptiness of the threats of racial strife which were used to inhibit the courts. N.Y. Times, Feb. 27, 1950, p. 17, col. 1. However, later his own home was attacked. 1d., Oct. 10, 1950, p. 28, col., 6; id., Oct. 12, 1950, p. 41, col. 1 .

52. Southern all-white juries have not been eliminated but service on mixed juries is no longer considered novel. 1950 BalAnCE SHEET at 29.

53. The reaction following the Supreme Court's requirement that interstate travel be integrated in Morgan v. Virginia, 328 U.S. 373 (1946) and Henderson v. United States, 339 U.S. 816 (1950) has not been violent. The carriers tend, however, to continue segregation informally by seating races at opposite ends of cars. 1950 BALANCE SHEEr' at 63. Just recently this policy received the blessing of the Interstate Commerce Commission, 20 U.S.L. WEEK 2382 (1952).

54. The Supreme Court was directly admonished by Attorney General Daniel of Texas when he summed up his oral argument in Sweatt v. Painter, 339 U.S. 629 (1950) with the warning that segregation was necessary to avoid race conflict because "some people have feelings that make for confict when the races associate too closely." N.Y. Times, April 5, 1950, p. 39, col. 6. But experience has shown that segregation was not necessary at the graduate level.

Liberal Virginius Dabney, who concedes that the courts have been responsible for much of the Negro's progress, cautions that these gains will be lost if pushed beyond southern public opinion. Id., March 22, 1951, p. 33, col. 5. But southern public opinion has almost uniformly shifted only after judicial support of the Negro's rights. For statements of Southerners on race relations in general, see Bilbo, TAKE Your CHorcESeparation or Mongrelization (1945); Collins, Whither Soltd South? (1947); LaAndry, The Cult of Equality (1945). 
These instances of southern adjustment to enforced desegregation strongly suggest that the normal reaction of the South to Supreme Court decisions is not violence. Generally, the only resistance takes the form of attempted circumvention. ${ }^{\text {55 }}$ Tighter decrees and persistent enforcement ultimately overcome even this type of resistance. ${ }^{.0}$ Thus there is little reason for the courts to allow threats of violence and civil strife to delay desegregation. ${ }^{57}$

55. The plan in Georgia, N.Y. Times, Feb. 18, 1951, p. 48, col. 1, and in South Carolina, id., March 17, 1951, p. 13, col. 4, to abandon public scliools and set up private schools for whites if segregation is declared unconstitutional illustrates the circumvention pattern. It resembles the election law manipulation with which the South attempted to neutralize the Court's attack on the white primary. Kex. Soutnens Politres c. 29 (1949). Recently Atlanta, Ga., cut the white-Negro vote ratio from 2-1 down to 3-1 by establishing new city boundaries which raised the white population from $67 \%$ to $72 \%$. The Nation, Feb. 23, 1952, p. 166. The "county unit" system, used in Georgis to minimize the weight of the Negro vote, is still constitutional. South v. Peters, 339 U.S. 276 (1950). Iraintenance of white political control is no less crucial to southerners than the maintenance of all white schools. And the threats of violence made when white primaries were endangered were as violent as those now voiced against educational desegration. The informal segregated seating pattern adopted by interstate carriers is another example of passive resistance rather than violent reaction to desegragation orders. See note $\mathbf{5 3}$ supra.

School district gerrymander is a ready device to limit the number of Negrass actually integrated. It is still used with success in sections of the North, MYrnan at 633, and would undoubtedly be used in the South.

56. The history of the white primary cases is the best example of legal victories over civil intransigence. Consult Key, Southers PoLitics c. 29 (1949).

57. The passibility of racial violence when school segregation breaks down cannot be denied. Rose \& Rose. The American Ncgro, 20 J. Negro En. 320, 323 (1951). But actually, due to southern residential segregation patterns, it is not likely that even a general desegregation decree would in fact cause drastic and immediate integratiun. Thompson, Negro Teachers and the Elimination of Segregation, $20 \mathrm{~J}$. NEaro ED. 135, 138 (1951).

Even assuming a violent reaction to desegregation, this danger from the standpoint of legal theory should not control. "It is urged that this proposed segregation will promote the public peace by preventing race confict. Desirable as this is, and important as is the preservation of the public peace, this aim cannot be accomplished by laws or ordinances which deny rights created or protected by the Federal Constitution." Euchanan v. Warley, 245 U.S. 60, 81 (1917).

Moreover, experiments in Detroit after the serious race riots of World War II demonstrate that racial conflict can be avoided if proper law enforcement precautions are taken. N.Y. Times, April 20, 1947, \$ VI, p. 17, col. 4. For instance, Chicago ufficials insisted a "mob can't run the city." And a riot protesting residential desegregation was suecessfully quelled while the city took immediate steps to improve further its riut contrul techniques. N.Y. Times, Dec. 11, 1946, p. 35, col. 4. The swimming pool desegregation cases also illustrate the efficacy of proper police precautions. See note 40 supra. For a complete discussion of racial disorders and the important preventive function played by the law and by enforcement agencies see Comment, Racial Fiolence and (ivil Rights Enforcement, 18 U. of CHI. L. Rev. 769 (1951). See also LeE, RACE Rrors Areit't NecesSARY (Public Affairs Pamphlet 1945); MacIver, The Mfore Perrect Union 178 (1948).

Finally, if the Court ficels that a blanket desegregation decree would precipitate too great social resistance, it might direct that schools be integrated from lindergarten to 
In the long run it is well established that segregation intensifies, rather than eases, racial tension. Instead of encouraging racial cooperation, it fosters mutual fear and suspicion which is the basis of racial violence. ${ }^{68}$ Thus, every inroad on racial segregation which courts can effect maximizes the opportunity for eventual racial reconciliation.

second grade the first year and then automatically one grade higher each ycar. In this way integration would grow up with the children. The mixing of younger children would be less likely to excite the community and valuable administrative experience would be achieved before the upper grades were integrated. Because the decree would assure automatic progressive integration each year, this gradual solution is not subject to the usual complaint against gradualism, i.e., that it is a dodge meant to give the impression of changes without any real progress. This plan would also provide time to solve the problem of surplus Negro teachers who will undoubtedly not be integrated immediately. But the overall teacher shortage should ameliorate even this difficulty. On the problem of Negro teachers, see Thompson, supra at 135. Such a disposition of the problem must hurdle the technical barrier of the Fourteenth Amendment's guarantee of a personal and immediate right to equality. See Sipuel v. Board of Regents, 332 U.S. 631, 633 (1948).

58. Segregation is recognized as one of the greatest barriers to better understanding between Negroes and whites. Davie, Negroes in Amerucan Society 310 (1949); Joinnson, Education and the Cultural Crisis 83 (1951) ; Maciver, The Mone Perfect Union (1948); Myrdal at 657; Roberts, Mental and Emotional Health Needs of Negro Children and Youth. 19 J. NEGRo ED. 351, 360 (1950).

Studies of integration in the armed forces, industry, merchant marine, and in housing projects have all documented the fact that increased contact and communication on an equal basis generally reduce prejudice. Interracial activity in the long run reduces rather than increases social tensions. Deutsch \& Collins, Interracial Housing 122-9 (1951); Rose, Studies in Reduction of Prejudice 13-14, 18-19 (1949). 